\title{
Potential therapeutic manipulations of the CXCR3 chemokine axis for the treatment of inflammatory fibrosing diseases
}

\section{[version 1; peer review: 2 approved]}

\author{
Morgan K. Groover (iD, Jillian M. Richmond (iD \\ Department of Dermatology, University of Massachussetts Medical School, Worcester, MA, 01605, USA
}

V1 First published: 05 Oct 2020, 9:1197

https://doi.org/10.12688/f1000research.26728.1

Latest published: 05 Oct 2020, 9:1197

https://doi.org/10.12688/f1000research.26728.1

\section{Abstract}

Chemokines play important roles in homeostasis and inflammatory processes. While their roles in leukocyte recruitment are wellappreciated, chemokines play additional roles in the body, including mediating or regulating angiogenesis, tumor metastasis and wound healing. In this opinion article, we focus on the role of CXCR3 and its ligands in fibrotic processes. We emphasize differences of the effects of each ligand, CXCL9, CXCL10 and CXCL11, on fibroblasts in different tissues of the body. We include discussions of differences in signaling pathways that may account for protective or pro-fibrotic effects of each ligand in different experimental models and ex vivo analysis of human tissues. Our goal is to highlight potential reasons why there are disparate findings in different models, and to suggest ways in which this chemokine axis could be manipulated for the treatment of fibrosis.

\section{Keywords}

CXCR3, CXCL9, CXCL10, CXCL11, fibrosis, fibroblast, pericyte, endothelial cell

\section{Open Peer Review \\ Approval Status \\ 1 \\ 2 \\ version 1 \\ 05 Oct 2020
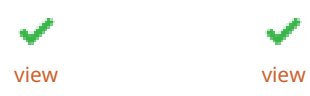

1. Christian D. Sadik ID, University of Lübeck, Lübeck, Germany

Center for Research on Inflammation of the Skin (CRIS), Lübeck, Germany

2. Patricia A. Pioli D, Geisel School of Medicine, Lebanon, USA

Any reports and responses or comments on the article can be found at the end of the article. 
Corresponding author: Jillian M. Richmond (jillian.richmond@umassmed.edu)

Author roles: Groover MK: Visualization, Writing - Original Draft Preparation, Writing - Review \& Editing; Richmond JM:

Conceptualization, Funding Acquisition, Project Administration, Visualization, Writing - Original Draft Preparation, Writing - Review \& Editing

Competing interests: JMR is an inventor on patent application \#15/851,651, "Anti-human CXCR3 antibodies for the Treatment of Vitiligo" which covers targeting CXCR3 for the treatment of vitiligo; and on patent \#62489191, "Diagnosis and Treatment of Vitiligo" which covers targeting IL-15 and Trm for the treatment of vitiligo. MKG declares no competing interests.

Grant information: JMR is supported by the National Institutes of Health [R56AR075761], a Career Development Award from the Dermatology Foundation, a Target Identification in Lupus Award from the Lupus Research Alliance and a Concept Award from the US Department of Defense Lupus Research Program [\#LR190030].

The funders had no role in study design, data collection and analysis, decision to publish, or preparation of the manuscript.

Copyright: ( 2020 Groover MK and Richmond JM. This is an open access article distributed under the terms of the Creative Commons Attribution License, which permits unrestricted use, distribution, and reproduction in any medium, provided the original work is properly cited.

How to cite this article: Groover MK and Richmond JM. Potential therapeutic manipulations of the CXCR3 chemokine axis for the treatment of inflammatory fibrosing diseases [version 1; peer review: 2 approved] F1000Research 2020, 9:1197

https://doi.org/10.12688/f1000research.26728.1

First published: 05 Oct 2020, 9:1197 https://doi.org/10.12688/f1000research.26728.1 


\section{Introduction: understanding CXCR3's typical and atypical functions}

Chemokine receptors are a subgroup of class A G-protein coupled receptors (GPCRs) that are relatively conserved across eukaryotes ${ }^{1}$. They bind to chemokine ligands, a special class of 8-10kDa chemotactic cytokines, which are classified based on their amino acid structure (e.g. CC, CXC, or CX3C) $)^{2}$. With a few exceptions, most ligand-receptor relationships are promiscuous, meaning that a single chemokine receptor has multiple ligands and a single chemokine can bind to multiple receptors. As of now, there are 18 known chemokine receptors with Gai-dependent chemotactic activity, and 5 atypical (non-chemotactic, recycling or scavenging) chemokine receptors in humans. Many chemokines are considered inflammatory, as they recruit leukocytes during inflammatory responses. However, there are also homeostatic chemokines that are important for immune cell maturation, tissue development, and angiogenesis. Homeostatic chemokines often exhibit tissue tropism, providing signals for recirculating immune cells, paracrine signals for cells that comprise tissues, and even tumor growth and metastasis ${ }^{3}$.

CXCR3 is typically considered to be an inflammatory chemokine receptor because it is expressed by leukocytes that migrate towards interferon-induced ligands to sites of tissue inflammation ${ }^{4}$. However, CXCR3 is also expressed on non-hematopoietic cells including endothelial cells, where it plays roles in promoting or inhibiting angiogenesis, and fibroblasts, in which it mediates wound healing responses.

There are several examples of diseases where inflammation precedes or is admixed with fibrosis, including infectious diseases (e.g. schistosomiasis, tuberculosis), cancers (e.g. pancreatic cancer, post-irradiation breast cancer) and autoimmune diseases (e.g. hepatitis, pulmonary fibrosis in scleroderma and skin fibrosis in morphea). Hallmarks of inflammatory fibrosis include infiltration of leukocytes; activation of endothelium; fibroblast activation, migration, proliferation and differentiation; production of collagen and other extracellular matrix proteins; and increased collagen bundle thickness and disorganization ${ }^{5}$. Data from our lab and others have demonstrated that the CXCR3 chemokine axis can mediate protective or pro-fibrotic signals depending upon the context of the involved organs. In this opinion article, we will discuss potential reasons for disparate findings, and provide our opinions about how this system can be targeted therapeutically for the treatment of fibrosis.

\section{CXCR3 signaling pathways in leukocytes}

CXCR3 has four extracellular domains that bind its ligands (CXCL9, CXCL10, and CXCL11), and four intracellular domains that mediate the receptor's different functions. The differential involvement of CXCR3 receptor domains in ligand binding and subsequent differences in downstream signaling contribute to the complex nature of this chemokine system, which has been mapped out in leukocytes using mutational constructs and competition binding assays. Like many other GPCRs, CXCR3-mediated chemotaxis is pertussis-toxin sensitive. However, CXCR3 activates several other pathways in addition to $\mathrm{G} \alpha$ subunit proteins, which we will review below.
CXCR3 binding and activation requires ligand interactions with at least one sulfated tyrosine in the $\mathrm{N}$ terminus and an interaction with amino acid residue R216 in the second extracellular loop ${ }^{6}$. The proximal 16 amino acid residues of the $\mathrm{N}$ terminus are required for CXCL10 and CXCL11 binding and activation, but not CXCL9 activation. R216 in the second extracellular domain plays no role in CXCL10 or CXCL11 binding or ligand-mediated internalization, but this residue is necessary to activate chemotaxis by all three CXCR3 ligands ${ }^{7}$. Both the DRY site, which encompasses the R216, and the CXCR3 carboxyl terminus are essential for CXCL9-, CXCL10-, and CXCL11-induced chemotaxis, calcium mobilization, and Erk phosphorylation (Figure 1A).

CXCR3 ligands selectively activate different receptor internalization pathways via $\beta$-arrestin and $\mathrm{G} \alpha \mathrm{i}$ family members. Differences in signaling pathway activation by each ligand is called biased agonism ${ }^{8,9}$. CXCL10-induced receptor internalization relies on the CXCR3 carboxyl terminus, dynamin and $\beta$-arrestin $1^{10}$. CXCL11 is the most potent inducer of CXCR3 internalization ${ }^{11}$, and dominant negative dynamin and $\beta$ arrestin 1 are unable to impede internalization ${ }^{10}$. The third intracytoplasmic loop is required for maximal CXCL11-induced internalization (Figure 1A).

In $\mathrm{T}$ cells, Gai2 is required for mediating CXCR3 ligand signaling, whereas Gai3 limits activation of this signaling pathway $^{12}$. Western blotting of peripheral blood leukocytes stimulated with CXCR3 ligands demonstrated that CXCL11 and, to a lesser extent, CXCL9/10 induce dose- and time-dependent phosphorylation of p44/42 MAPK (ERK) and Akt that is prevented by pertussis toxin treatment (inhibition of $\mathrm{G} \alpha$ subunit binding) ${ }^{13}$. However, inhibition of MEK/ERK (U0126 or PD98059) does not prevent CXCL11-mediated chemotaxis, whereas PLC inhibition (U73122), PI3K (wortmannin) or, to a lesser extent, AKT inhibition (LY294002) does abrogate or reduce human $\mathrm{T}$ cell migration, respectively. Akt activation in human T cells was recently reported to be dependent upon $\beta$-arrestin $2^{14}$.

There is increasing evidence that chemokine receptors can mediate JAK/STAT signaling, which has typically been attributed to common gamma chain cytokine signaling ${ }^{15}$. While JAK activation downstream of CXCR3 has not yet been studied, STAT activation in response to incubation with CXCL9/10/11 has been assessed in $\mathrm{T}$ cell cultures: addition of recombinant CXCL9/10 activates STAT1/STAT5 to promote Th1 and/or Th17 differentiation via Tbet/ROR $\gamma \mathrm{T}$ expression, whereas CXCL11 activates STAT3/ STAT6 via GATA3 expression to augment regulatory function ${ }^{16}$.

\section{CXCR3 signaling pathways in vascular endothelial} cells, smooth muscle cells, pericytes and fibroblasts CXCR3 is also expressed by some non-hematopoietic cells, including endothelial cells, smooth muscle cells and fibroblast subsets. In endothelial cells, CXCR3 ligands mediate pro- or anti-angiogenic signals depending upon the model and tissue of origin. CXCL10 inhibits VEGF-induced dermal endothelial cell motility and tube formation in vitro via cAMP, PKA and MEK inhibition of m-calpain; this likely serves as a way to 


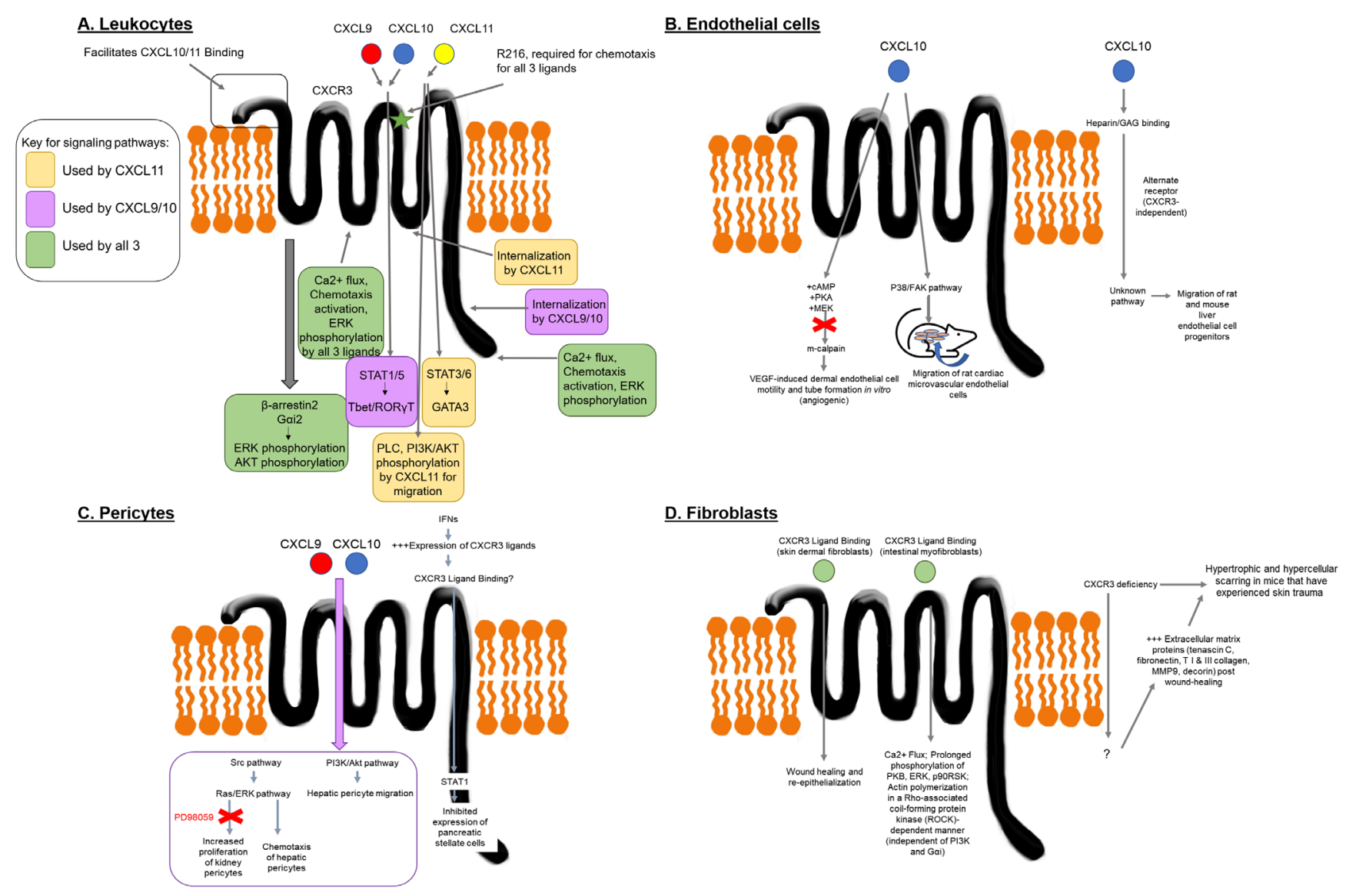

Figure 1. CXCR3 signaling pathways in different cell types. (A) Major CXCR3 signaling pathways in leukocytes. CXCL9, CXCL10 or CXC11 bind to CXCR3 to mediate chemotaxis and T cell skewing. Different domains facilitate ligand binding, with the N terminus of CXCR3 facilitating binding of CXCL10 and CXC11. R216 in the second extracellular loop (green star) is required for chemotactic responses for all 3 ligands. All three ligands can induce calcium flux, PERK, and pAKT, though CXCL9/10 require Gai2 for pERK and $\beta$-arrestin2 for pAkt. CXCL11 can activate PLC and PI3K/AKT to mediate migration independent of Gai. Internalization of CXCR3 induced by CXCL9/10 requires the C terminus, whereas CXC11 requires the 3rd intracellular loop. CXCL9/10 can activate STAT1/5 to enforce Tbet/RORYT expression, whereas CXCL11 activates STAT3/6 to enforce GATA3 expression. (B) CXCR3-dependent and independent signaling pathways in endothelial cells. CXCL10 activates CAMP, PKA and MEK in dermal endothelial cells to inhibit m-calpain and dampen angiogenesis. In cardiac microvascular endothelial cells, CXCL10 activates the p38/FAK pathway to induce migration, but not proliferation. CXCL10 also exerts effects on endothelial cells independently of CXCR3, but in a manner that requires GAG binding. (C) CXCR3 signaling in pericytes. Pericytes activate Src, Ras/ERK and PI3K/AKT pathways downstream of CXCR3, which mediate chemotactic responses. Kidney pericytes exhibit increased proliferation downstream of CXCL9/10, which is ERK-dependent (inhibited by PD98059). Interferons inhibit proliferation of pancreatic stellate cells via STAT1, though it is unclear whether this response is via CXCR3 ligands. (D) Fibroblast responses to CXCR3 ligands. Intestinal myofibroblasts exhibit calcium flux and phosphorylation of PKB, ERK, p90RSK induced by all three ligands. All three ligands induce actin polymerization in a Rho-associated coiled coil-forming protein kinase (ROCK)-dependent manner that is independent of PI3K and Gai. Signaling in skin dermal fibroblasts has not been fully mapped, though CXCR3 deficiency leads to hypertrophic and hypercellular scarring in mice via increased extracellular matrix proteins, including tenascin C, fibronectin, type I \& III collagen, MMP9 and decorin. Color key: CXCL9 = red; CXCL10 = blue; CXCL11 = yellow; CXCL9/10 = purple; CXCL9/10/11 = green .

inhibit angiogenesis late in the wound healing process ${ }^{17}$. CXCL10 exhibits angiostatic properties in non-small cell lung cancer and idiopathic pulmonary fibrosis ${ }^{18,19}$. CXCL10 is also able to induce angiostatic effects by binding glycosaminoglycans (GAGs) independently of CXCR3 ${ }^{20}$. However, CXCL10 induces migration, but not proliferation, of rat cardiac microvascular endothelial cells via the p38/FAK pathway ${ }^{21}$ and rat and mouse liver endothelial cell progenitors through an unknown pathway ${ }^{22}$ (Figure 1B).

Pericytes are contractile cells on capillaries and post-capillary venules in tissues that play integral roles in tissue healing 
and remodeling ${ }^{23}$. Examples include hepatic stellate cells in the liver, glomerular mesangial cells in the kidney and pancreatic stellate cells. Pericytes express CXCR3, and activate the Src, Ras/ERK, and PI3K/Akt pathways downstream of CXCR3 ligand binding ${ }^{24}$. Inhibitor studies indicate that Src and subsequent Ras/ERK activation are required for chemotaxis of hepatic pericytes, which is in direct contrast to observations in $\mathrm{T}$ cells. PI3K/Akt also plays an important role in hepatic pericyte migration as evidenced by abrogation of CXCL10 migration in the presence of wortmannin or LY294002. In addition to chemotaxis, kidney pericytes exhibit increased proliferation downstream of CXCL9/10, which is ERK-dependent (inhibited by PD98059). Unlike hepatic pericytes, kidney pericytes exhibit a second wave of ERK phosphorylation following incubation with CXCL10. CXCR3 signaling in pancreatic stellate cells has not been as extensively mapped, but they respond to PDGF by activating Src-JAK2-STAT3 ${ }^{25}$. Interferons (IFNs), which drive expression of CXCR3 ligands, inhibit proliferation of pancreatic stellate cells via STAT1 ${ }^{26}$ (Figure 1C).

CXCR3 plays a homeostatic role in wound healing and re-epithelialization responses by fibroblasts ${ }^{27-29}$. CXCR3 deficiency leads to hypertrophic and hypercellular scarring in mice that have experienced skin trauma ${ }^{30,31}$. While CXCR3-mediated signaling in skin fibroblasts has not been well-characterized, the consequence of loss of signaling during wound healing includes increases in extracellular matrix proteins including tenascin C, fibronectin, type I \& III collagen, MMP9 and decorin 180 days post-wounding compared to WT controls ${ }^{31}$.

Studies of CXCR3 signaling downstream of CXCL9 and CXCL10 in intestinal myofibroblasts have shown modest differences in signaling, including CXCL9/10-induced calcium flux at $10 \mathrm{~min}$ versus $8 \mathrm{~min}$ for CXCL11, and prolonged phosphorylation of PKB, ERK, p90RSK induced by all 3 ligands as compared to shorter phosphorylation time in peripheral blood leukocytes (e.g. 2-20min versus $1-2 \mathrm{~min})^{32}$. All three ligands induce actin polymerization in a Rho-associated coiled coil-forming protein kinase (ROCK)-dependent manner that is independent of PI3K and Gai (Figure 1D). Further detailed signaling pathway analyses for CXCL9/10/11 signaling are warranted in non-hematopoietic cells from different organs.

\section{Post-translational modifications, proteolytic processing and potential alternate receptors for the CXCR3 chemokine axis}

Post-translational modifications of the CXCR3 chemokine axis modulates the function and signaling ability of the ligands and their receptor. CXCL10/11 have heparin binding sites that allow it to be presented on endothelium ${ }^{33}$. CXCL10 presentation by the endothelium requires oligomerization ${ }^{34}$. CXCL10/11 may be citrullinated by peptidylarginine deiminase, which inhibits their ability to induce chemotaxis and calcium flux and reduces their ability to bind heparin ${ }^{35}$. CXCR3 itself requires tyrosine sulfation to bind to its ligands and mediate chemotaxis ${ }^{6}$.

CXCL9/10/11 are cleaved/truncated by CD26, and CXCL11 is cleaved by $\mathrm{CD} 13^{36,37}$. The $\mathrm{CD} 26$ truncations of CXCR3 ligands retain angiostatic activity while losing CXCR3-mediated signaling $^{38}$. The C' terminus of CXCL9 can inhibit neutrophil migration via competition with CXCL8-mediated binding to heparin, heparan sulfate, and cellular GAGs, which normally facilitate adhesion to vessels and subsequent transmigration ${ }^{39,40}$. CD13 is expressed by endothelial and epithelial cells as well as fibroblasts in angiogenic tissue, but not normal tissue ${ }^{41}$. Truncation of just the first two amino acids in CXCL11 by CD13 abrogates Akt and ERK phosphorylation and greatly reduces calcium flux to prevent migration of CXCR3-transfected $\mathrm{CHO}$ cells $^{36}$. Truncation of the first six amino acids still retains angiostatic activity as assessed by scratch assay of endothelial cell cultures.

There are two other isoforms of CXCR3: CXCR3-B which binds to CXCL4 and mediates angiostatic effects in cultured human endothelial cells ${ }^{42}$; and CXCR3-alt which binds CXCL1 $11^{43}$. Of note, C57BL/6 (B6) mice do not express CXCR3-B ${ }^{20}$. The roles of CXCR3-B and CXCR3-alt in fibrosis have not been studied. CXCR3 can also crosstalk with CXCR4 and CXCR7 via CXCL11 and CXCL12 ${ }^{44}$. CXCR4 mediates profibrotic effects in the liver, while CXCR7 mediates more homeostatic regenerative responses ${ }^{45}$. CXCL9 can induce heterologous desensitization of CXCR4 to its ligand CXCL12 ${ }^{46}$. Notably, autoantibodies against CXCR3 and CXCR4 correlate with increased lung and skin disease severity in scleroderma patients, though it is unclear exactly how these impact signaling ${ }^{47,48}$. CXCL11 binds to CXCR7, which is expressed on activated endothelial cells, tumor cell lines and fetal liver cells $^{49}$. CXCL11 ligation by CXCR7, which has an affinity of $2-5 \mathrm{nM}$, does not induce calcium flux or migration; rather it promotes survival and adhesion. CXCR7 has been proposed to be a scavenger receptor for CXCL11 ${ }^{50}$. CXCR7 can attenuate TGF $\beta$ signaling in the lung, though the role of CXCL11 in this process has not been studied ${ }^{51,52}$.

\section{Profibrotic roles of CXCR3 ligands}

CXCR3 and its ligands are reported to promote fibrosis in certain disease models and organs. An important caveat to bear in mind when assessing B6 mouse models is that CXCL11 is not expressed in this strain due to a null mutation. However, CXCL9 and CXCL10 knockout mice were generated using 129 oocytes and were backcrossed to B6. Therefore, WT B6 mice express CXCL9 and CXCL10, CXCL9-/- mice express CXCL10 and CXCL11, and CXCL10-/- mice express CXCL9 and CXCL11. This means that while CXCL11 cannot be directly assessed in B6 models, insights about its function can be gleaned by comparing CXCL9-/-, CXCL10-/- and WT B6 mice.

The nephrotoxic serum nephritis model of inflammatory kidney disease, which exhibits tubulointerstitial fibrosis, is dependent on CXCR3 and CXCL9, but not CXCL10, as determined by histopathology and loss of renal function ${ }^{53}$. CXCR3-/- and CXCL9-/- mice had fewer intrarenal activated $\mathrm{T}$ cells and macrophages, as well as fewer IgG glomerular deposits and antigen-specific IgG in serum. These data suggest that CXCR3 and CXCL9 initiate nephritis through cellmediated events, which ultimately promote tubulointerstitial 
fibrosis. CXCL10-/- animals developed kidney disease similar to WT controls, indicating that any potential antifibrotic role of CXCL11 in the kidney is potentially nullified by profibrotic effects of CXCL9. Similarly, any potential profibrotic role of CXCL11 in CXCL9-/- mice may be nullified by antifibrotic effects of CXCL10. However, a Balb/c mouse model of unilateral ureteral obstruction-induced renal tubulointerstitial fibrosis was exacerbated by JAK inhibition, and STAT3 played a protective role $^{54}$. Several factors may contribute to the disparate findings between these models, namely whether the process is immune-mediated or obstructive nephropathy, which other signals are being disrupted by JAK inhibition, and whether all three CXCR3 ligands are present to balance pro- versus anti-fibrotic signaling (Table 1).

Morphea, or localized scleroderma, is an inflammatory fibrosing disease of the dermis and underlying tissue. Several studies have identified CXCR3 ligands as positively correlating with disease severity and activity in patients ${ }^{55-57}$. Systemic sclerosis, or scleroderma, also exhibits upregulation of CXCR3 ligands that correlates with disease severity ${ }^{58}$. Preliminary studies from our laboratory support a pro-fibrotic role of CXCL9 in the skin: CXCL9-/- mice are protected from bleomycininduced skin fibrosis, and in vitro treatment of mouse and human fibroblasts with CXCL9 induces transcription of collagen 1a1 (colla1); these data are available on a preprint server and are currently undergoing peer review ${ }^{59}$.

CXCL10 has pro-fibrotic effects in the liver, where it prevents NK cells from inactivating hepatic stellate cells ${ }^{60}$. CXCL10-/mice and WT mice treated with anti-CXCL10 antibody are protected from carbon tetrachloride-induced liver fibrosis. Hepatic stellate cells upregulate CXCR3 in response to carbon tetrachloride, and CXCL10 induces their migration but not proliferation. CXCL10 also mediates $\mathrm{T}$ and B cell aggregates in lymphoid tissue, which are essentially absent in CXCL10-/mice (Table 1).

\section{Antifibrotic roles of CXCR3 ligands}

While CXCL9 has pro-fibrotic effects in renal and skin tissue, CXCL9 has direct angiostatic and antifibrotic effects in experimental models of pancreas and liver fibrosis. In the trinitrobenzene sulfonic acid (TNBS) induced-pancreatitis rat model, administration of anti-CXCL9 antibody worsened fibrosis, whereas administration of recombinant CXCL9 improved fibrosis, as assessed by trichrome staining and hydroxyproline assay ${ }^{61}$ (Table 1). In vitro stimulation of pancreatic stellate cells with CXCL9 downregulated TGF $\beta 1$ and col1a1 production by confocal microscopy. Of note, antibody and recombinant CXCL9 were administered subcutaneously (s.c.) to rats in this model. We hypothesize that this route of administration may have pulled inflammatory infiltrates away from the gastrointestinal (GI) tract and towards the skin, considering there was $1.5 \mathrm{ng} / \mathrm{mL}$ CXCL9 in serum and approximately $30 \mu \mathrm{g}$ was administered s.c. daily (assuming average weight of $300 \mathrm{~g} / \mathrm{rat}$ at a dose of $100 \mu \mathrm{g} / \mathrm{kg}$ body weight).
In the carbon tetrachloride-induced liver fibrosis model, CXCR3-/- mice exhibited augmented liver damage at $24 \mathrm{~h}^{62}$. Follow-up studies from the same laboratory used mice treated exogenously with CXCL9, which reduced the severity of liver fibrosis as assessed by Sirius red staining, hydroxyproline assay, and $\alpha$-SMA expression ${ }^{63}$ (Table 1). In vivo CXCL9 treatment also inhibited angiogenesis as assessed by CD31 staining and ultrasound visualization of liver perfusion. However, CXCL9 treatment did not impact the number of Th1-polarized, IFN- $\gamma$-positive cells in the liver amongst treatment groups. Treatment of endothelial cells in vitro with CXCL9 was able to inhibit VEGF-mediated proliferation and migration via PLC $\gamma$, JNK and ERK. In vitro treatment of hepatic stellate cells reduced TGF $\beta$ and colla1 by protein and RNA ${ }^{64}$.

While CXCL10 has profibrotic effects in the liver, CXCL10 limits lung fibrosis in the murine model of bleomycin-induced pulmonary fibrosis (Table 1). CXCR3-/- and CXCL10-/- mice display exaggerated pulmonary fibrosis after bleomycin administration, and transgenic mice overexpressing CXCL10 are protected from bleomycin-induced mortality ${ }^{65,66}$. Bleomycin did not alter the $\mathrm{T}$ cell cytokine milieu in CXCL10-/- mice, weakening the support for the idea that CXCL10 might limit fibrosis by skewing $\mathrm{T}$ cell polarization to the Th1 phenotype as demonstrated in hepatitis models. CXCL10 also did not decrease lung tissue-derived angiogenic activity and von Willebrand Factor expression after bleomycin delivery, despite that angiogenesis is considered a rate-limiting step in the development of pulmonary fibrosis. CXCR3 mRNA, but not protein, was detected in lung fibroblasts. Rather, direct interaction of the heparin-binding domain of CXCL10 and syndecan-4 on the lung interstitial compartment inhibits fibroblast recruitment, TGF $\beta$ signaling and subsequent fibrosis ${ }^{67,68}$. Similar findings were reported in myocardium, which required CXCL10 fibroblast responses through proteoglycans ${ }^{69}$, and urethral fibrosis, in which CXCL10 signaling interfered with profibrotic TGF $\beta$ signaling ${ }^{70}$.

Similar to CXCL10, CXCL11 attenuates lung fibrosis in the bleomycin mouse model and inhibits angiogenesis in the corneal micropocket assay ${ }^{71}$ (Table 1). A double-blind, placebo controlled study of 330 idiopathic pulmonary patients treated with subcutaneous IFN- $\gamma$ 1b treatment exhibited increased CXCL11 in bronchoalveolar lavage fluid and plasma, with concomitant decreased elastin ${ }^{72}$. The pro- and anti-fibrotic roles of the CXCR3 ligands in different organs are summarized in Table 2.

\section{Potential therapeutic manipulations of CXCR3 for the treatment of fibrosis}

To select how to manipulate CXCR3 and/or its ligands for the treatment of fibrosis, it is our opinion that the suspected cell-of-origin in the fibrotic response and the level of angiogenesis during fibrogenesis need to be assessed. Based on the evidence discussed above, we hypothesize that fibrosing disorders primarily mediated by pericyte-type cells that require ERK signaling and exhibit more angiogenesis as a disease 


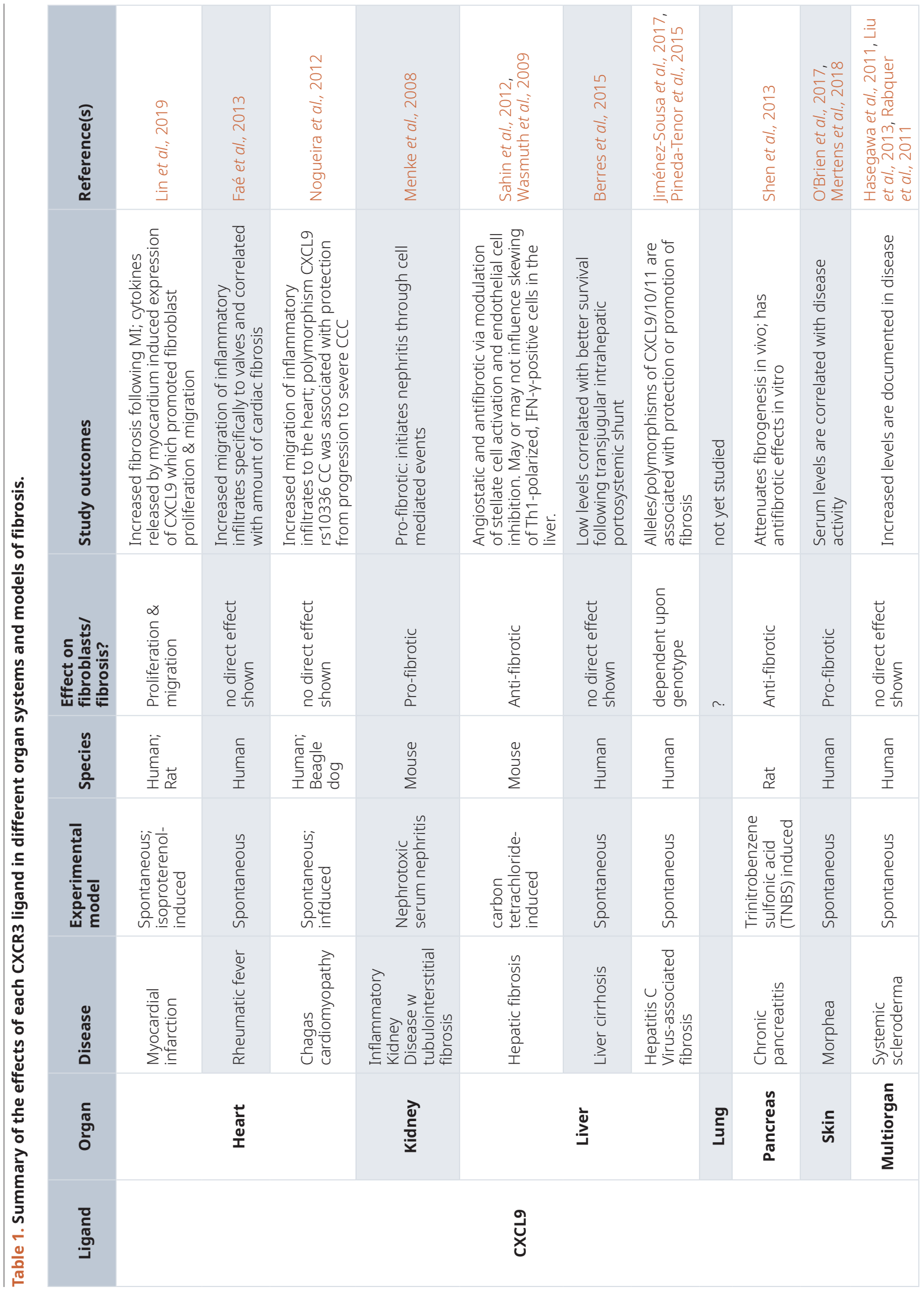




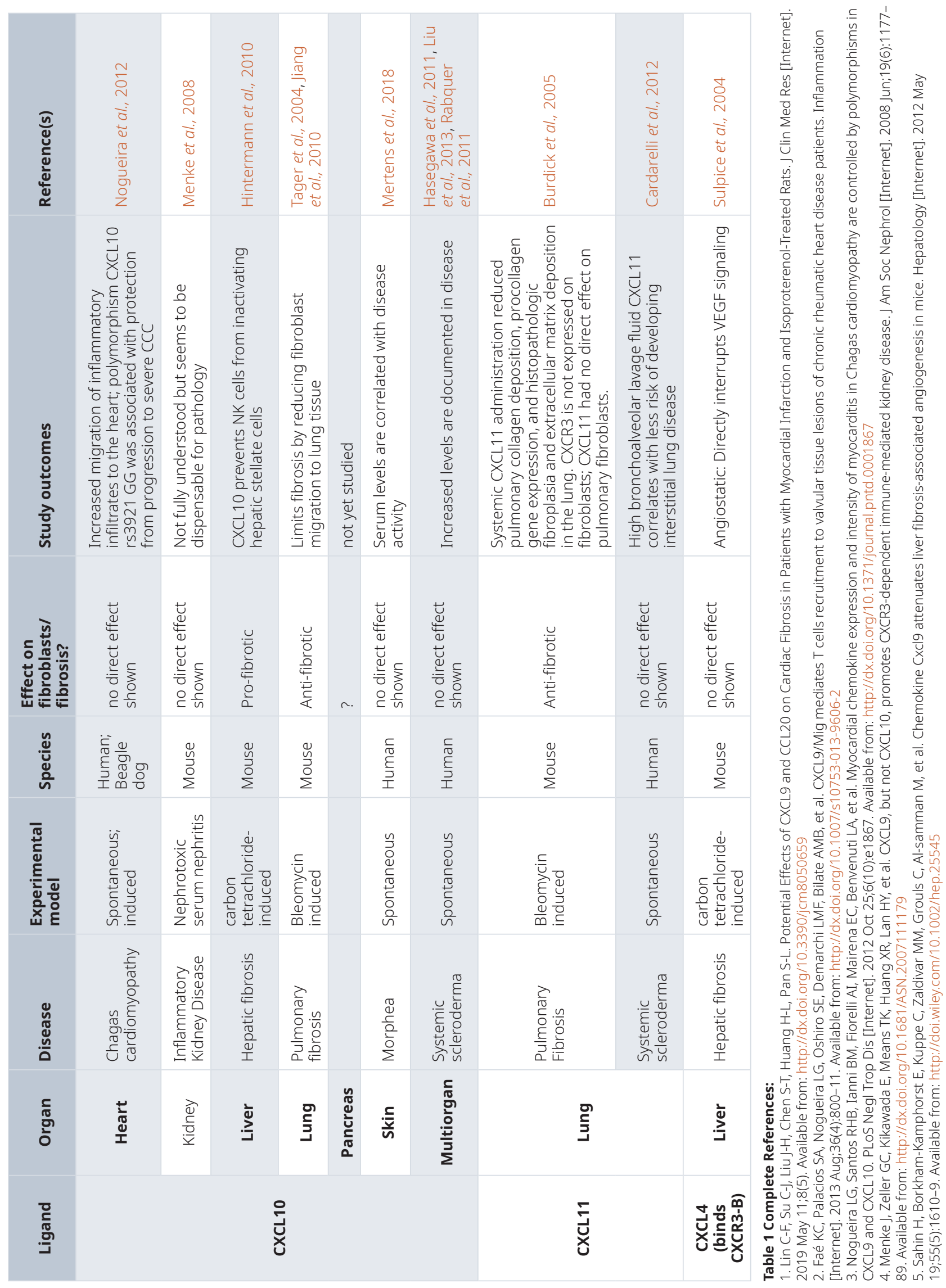




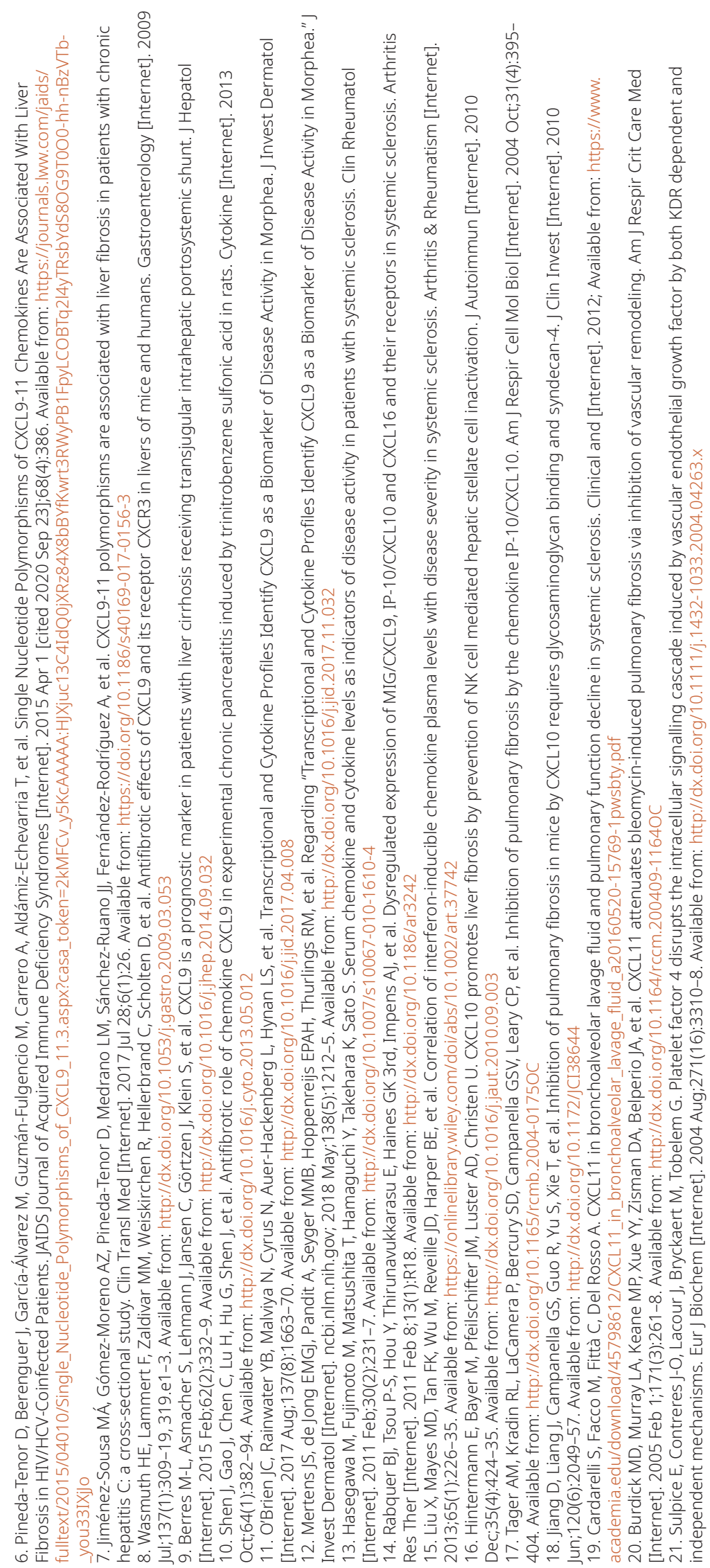


Table 2. Comparison of CXCR3 ligand actions in organ fibrosis.

\begin{tabular}{|l|l|l|l|}
\hline & CXCL9 & CXCL10 & CXCL11 \\
\hline Profibrotic & Heart, Kidney, Skin & Heart, Liver & $?$ \\
\hline Antifibrotic & Liver, Pancreas & Lung & Lung \\
\hline
\end{tabular}

feature would be more dependent upon CXCL10, and fibrosing disorders primarily mediated by fibroblast or myofibroblast-type cells that require AKT and JAK signaling and exhibit less vascular involvement would be more dependent upon CXCL9. For example, hepatic fibrosis has prominent vascular changes and is driven by hepatic stellate cells and CXCL10, whereas morphea has a low incidence of vascular changes and is driven by fibroblasts/myofibroblasts and CXCL9. GI organs, in which fibrosis is driven by pericytes, also generally seem to use CXCL9 for protective responses, whereas lung and skin, in which fibrosis is driven by fibroblast subsets, use CXCL10 for protective responses. Nuances in the signaling pathways, the relative chemokine responsiveness, as well as potential coreceptors, will need to be addressed in future studies. Technologies such as single cell RNA sequencing and proteomics may ultimately help resolve the heterogeneity of chemokine receptor and coreceptor expression, as well as preferential signaling pathway usage.

The first potential class of small molecules that could be used to disrupt CXCR3-mediated inflammatory fibrosis are JAK inhibitors. We and others have shown that JAK inhibitors prevent fibrosis in mice m $^{73-75}$, and demonstrated efficacy in our case studies of human morphea patients who were recalcitrant to standard therapies ${ }^{73,76}$. In our study of intradermal bleomycin injection in mice and human morphea tissue, we observed p-STAT1 and p-STAT3 activation in both immune infiltrates and cells with fibroblast morphology ${ }^{73}$. Notably, STAT1, STAT3 and STAT5 have predicted binding sites in the collagen 1a1 (colla1) promoter and enhancer regions (GeneCards), which may account for our observation that JAK inhibitors were able to suppress colla1 transcription by human and mouse fibroblasts in vitro ${ }^{73}$. We also noted that the JAK $1 / 2$ inhibitor ruxolitinib yielded a slightly better $p$ value than the JAK $3>>1>2$ inhibitor tofacitinib for inhibition of dermal thickening in the intradermal bleomycin mouse model. These data are in agreement with previously published studies examining JAK2 as a driver of fibrosis in scleroderma fibroblasts and a bleomycin mouse model ${ }^{74}$. Zhang et al demonstrated that following long-term selective inhibition of JAK2, JAK2 may be transphosphorylated by JAK1 to mediate fibrosis ${ }^{77}$, supporting the use of a combination JAK1/2 inhibitor for treatment of fibrosis. It is interesting to note that ruxolitinib was originally FDA approved for myelofibrosis ${ }^{78}$, and patients receiving ruxolitinib therapy often resolve fibrosis ${ }^{79}$. While this is encouraging for potential repurposing of ruxolitinib for other fibrosing diseases, we would caution that careful tapering and monitoring is needed to prevent potential rebound effects $^{80,81}$. Cessation of ruxolitinib can cause hyperphosphorylation of JAK2, increasing inflammation and subsequent fibrosis $^{82}$. Selecting a JAK1/2 inhibitor with a longer half-life, such as baricitinib ${ }^{83}$, might be a safer option for patients who are tapering.

The second potential class of therapeutics would be agonist peptides to mimic the antifibrotic role of CXCL10 for lung fibrosis. As suggested by Tager and Jiang et al, maintaining heparin binding but excluding CXCR3 binding would mitigate potential toxicities related to $\mathrm{T}$ cell recruitment ${ }^{65,67}$. CXCL10-based therapeutics might also prove useful for improving lung fibrosis and function in patients recovering from infectious lung disease, particularly Sars-CoV2 infection/COVID-19 disease ${ }^{84}$. Smith et al recently reported biased agonists of CXCR3 that can differentially mediate inflammation and migration of immune cells which they examined in the context of contact hypersensitivity in $\operatorname{skin}^{14}$, providing a basis for the feasibility of this approach.

The third potential class of therapeutics would be agents that inhibit the pro-fibrotic signaling events mediated by CXCR3 ligands, such as CXCL9 in Th1/IFN $\gamma$-driven kidney disease or morphea. These approaches could include anti-CXCL9 blocking/neutralizing antibodies, CXCL9 siRNA, or antagonistic peptide ligands. Of note, antibody neutralization of CXCL10 for treatment of hepatic fibrosis may be challenging, as CXCL10 antibodies neutralize the free form and not endothelial-bound chemokine $^{85}$. Similar challenges may arise when attempting to neutralize CXCL9 with antibody, as would anti-drug antibody responses.

A fourth class of therapeutics could leverage the cell- or organ-specific context of chemokine expression. For example, stimulating $\gamma \delta$ T-cells to produce CXCL10 in the lung could have therapeutic benefits in pulmonary fibrotic disease. Inhibiting macrophage production of CXCL9 in the skin could prevent collagen deposition in morphea. Drawing immune infiltrates away from the pancreas and towards the skin could reset the fibrotic process, as in the TNBS-induced rat model. Agents are in development to target specific cell types, such as antibody-drug conjugates $^{86}$ some with cleavable linkers ${ }^{87}$, bispecific antibodies ${ }^{88,89}$ and nanoparticles ${ }^{90}$, which can be preferentially phagocytosed by antigen presenting cells of the immune system. These could be leveraged to achieve the aforementioned goals of stimulating CXCL10 or inhibiting CXCL9 production by key cell types. Different drug delivery routes and systems may also help accomplish the goal of drawing immune cells away from the pancreas or other organs, with cutaneous administration via creams, injections or microneedle patches ${ }^{91}$ helping to achieve a high local concentration.

A fifth class of therapeutics could leverage existing enzymatic cleavage of CXCR3 ligands. Recombinant peptides lacking amino-terminal amino acids can exert angiostatic effects, while inhibiting CXCR3-mediated migration. Administration of bioactive CD26 and/or CD13, or inhibitors of these enzymes, may modulate fibrotic processes in specific organs or diseases. CD26 inhibitors have been reported to reduce or prevent fibrosis in models of myocardial fibrosis, lung fibrosis and kidney fibrosis ${ }^{92-94}$, and a CD13 inhibitor improved fibrosis in a mouse model of silica-induced lung fibrosis ${ }^{95}$. 
Last, combination therapies targeting both prevention of inflammation and fibrosis in addition to promoting tissue remodeling will likely provide the best therapeutic outcome for fibrosis patients ${ }^{96}$. Tissue remodeling will ultimately allow for breakdown of fibrotic plaques and better disease outcomes, which could be achieved through agonists or inducers of matrix metalloproteinases (MMPs) or antagonists of tissue inhibitors of MMPs (TIMPs).

\section{Conclusion}

The differential impact of CXCR3 and its ligands on tissues depends on disparate signaling pathways involving multiple cell types and potential coreceptors; the nuances of which should be addressed in future research involving single cell RNA sequencing and proteomics. As we have examined the known fibrotic and antifibrotic roles of CXCR3 and its ligands, we suggest that future therapeutic options should be centered around the suspected cell-of-origin in the fibrotic response, tissue-specific signaling factors and the degree of angiogenesis is during fibrosis. Likely, a combination of these therapies will have the best potential to ameliorate symptoms of patients with fibrosing diseases.

\section{Data availability}

No data are associated with this article.

\section{Acknowledgements}

We thank M. Tuzova and C. Garelli for insightful comments.
1. Proudfoot AEI: Chemokine receptors: multifaceted therapeutic targets. Nat Rev Immunol. 2002; 2(2): 106-15.

PubMed Abstract | Publisher Full Text | Free Full Text

2. Griffith JW, Sokol CL, Luster AD: Chemokines and chemokine receptors: positioning cells for host defense and immunity. Annu Rev Immunol. 2014 32: 659-702.

PubMed Abstract | Publisher Full Text

3. Zlotnik A, Burkhardt AM, Homey B: Homeostatic chemokine receptors and organ-specific metastasis. Nat Rev Immunol. 2011; 11(9): 597-606. PubMed Abstract | Publisher Full Text

4. Groom JR, Luster AD: CXCR3 ligands: redundant, collaborative and antagonistic functions. Immunol Cell Biol. 2011; 89(2): 207-15. PubMed Abstract | Publisher Full Text | Free Full Text

5. Wynn TA: Common and unique mechanisms regulate fibrosis in various fibroproliferative diseases. J Clin Invest. 2007; 117(3): 524-9. PubMed Abstract | Publisher Full Text | Free Full Text

6. Colvin RA, Campanella GSV, Manice LA, et al.: CXCR3 requires tyrosine sulfation for ligand binding and a second extracellular loop arginine residue for ligand-induced chemotaxis. Mol Cell Biol. 2006; 26(15): 5838-49. PubMed Abstract | Publisher Full Text | Free Full Text

7. Xanthou G, Williams TJ, Pease JE: Molecular characterization of the chemokine receptor CXCR3: evidence for the involvement of distinct extracellular domains in a multi-step model of ligand binding and receptor activation. Eur JImmunol. 2003; 33(10): 2927-36. PubMed Abstract | Publisher Full Tex

8. Zidar DA, Violin JD, Whalen EJ, et al.: Selective engagement of $\mathbf{G}$ protein coupled receptor kinases (GRKs) encodes distinct functions of biased ligands. Proc Natl Acad Sci U S A. 2009; 106(24): 9649-54. PubMed Abstract | Publisher Full Text | Free Full Text

9. Rajagopal S, Bassoni DL, Campbell JJ, et al.: Biased agonism as a mechanism for differential signaling by chemokine receptors. J Biol Chem. 2013; 288(49): 35039-48.

PubMed Abstract | Publisher Full Text | Free Full Text

10. Colvin RA, Campanella GSV, Sun J, et al.: Intracellular domains of CXCR3 that mediate CXCL9, CXCL10, and CXCL11 function. J Biol Chem. 2004; 279(29): 30219-27.

PubMed Abstract | Publisher Full Text

11. Sauty A, Colvin RA, Wagner L, et al.: CXCR3 internalization following T cellendothelial cell contact: preferential role of IFN-inducible T cell alpha chemoattractant (CXCL11). J Immunol. 2001; 167(12): 7084-93. PubMed Abstract | Publisher Full Text

12. Thompson $\mathrm{BD}$, Jin $\mathrm{Y}, \mathrm{Wu} \mathrm{KH}$, et al.: Inhibition of $\mathbf{G}$ alpha i2 activation by $\mathbf{G}$ alpha i3 in CXCR3-mediated signaling. J Biol Chem. 2007; 282(13): 9547-55. PubMed Abstract | Publisher Full Text | Free Full Text

13. Smit MJ, Verdijk P, van der Raaij-Helmer EMH: CXCR3-mediated chemotaxis of human $\mathrm{T}$ cells is regulated by a $\mathrm{Gi}$ - and phospholipase $\mathrm{C}$-dependent pathway and not via activation of MEK/p44/p42 MAPK nor Akt/PI-3 kinase. Blood. 2003; 102(6): 1959-65.

PubMed Abstract | Publisher Full Text

14. Smith JS, Nicholson LT, Suwanpradid J, et al.: Biased agonists of the chemokine receptor CXCR3 differentially control chemotaxis and inflammation. Sci Signal. 2018; 11(555): eaaq1075. PubMed Abstract | Publisher Full Text | Free Full Text

15. Soriano SF, Serrano A, Hernanz-Falcó n $P$, et al:: Chemokines integrate JAK/STAT and G-protein pathways during chemotaxis and calcium flux responses. Eur J Immunol. 2003; 33(5): 1328-33. PubMed Abstract | Publisher Full Text

16. Zohar Y, Wildbaum G, Novak R, et al: CXCL11-dependent induction of FOXP3negative regulatory $T$ cells suppresses autoimmune encephalomyelitis. Clin Invest 2014: 124(5): 2009-22.

PubMed Abstract | Publisher Full Text | Free Full Text

17. Bodnar RJ, Yates CC, Wells A: IP-10 blocks vascular endothelial growth factor-induced endothelial cell motility and tube formation via inhibition of calpain. Circ Res. 2006; 98(5): 617-25. PubMed Abstract | Publisher Full Text | Free Full Text

18. Arenberg DA, Kunkel SL, Polverini PJ, et al.: Interferon-gamma-inducible protein 10 (IP-10) is an angiostatic factor that inhibits human non-small cell lung cancer (NSCLC) tumorigenesis and spontaneous metastases. J Exp Med. 1996; 184(3): 981-92. PubMed Abstract | Publisher Full Text | Free Full Text

19. Keane MP, Arenberg DA, Lynch JP 3rd, et al.: The CXC chemokines, IL-8 and IP10 , regulate angiogenic activity in idiopathic pulmonary fibrosis. J Immunol. 1997: 159(3): 1437-43. PubMed Abstract

20. Campanella GSV, Colvin RA, Luster AD: CXCL10 can inhibit endothelial cell proliferation independently of CXCR3. PLoS One. 2010; 5(9): e12700. PubMed Abstract | Publisher Full Text | Free Full Text

21. Xia JB, Mao CZ, Chen ZY, et al:: The CXCL10/CXCR3 axis promotes cardiac microvascular endothelial cell migration via the P38/FAK pathway in a proliferation-independent manner. Exp Mol Pathol. 2016; 100(2): 257-65. PubMed Abstract | Publisher Full Text

22. Ling CC, Ng KTP, Shao Y, et al.: Post-transplant endothelial progenitor cell mobilization via CXCL10/CXCR3 signaling promotes liver tumor growth. J Hepatol. 2014; 60(1): 103-9.

PubMed Abstract | Publisher Full Text

23. Attwell D, Mishra A, Hall CN, et al.: What is a pericyte? J Cereb Blood Flow Metab. 2016; 36(2): 451-5.

PubMed Abstract | Publisher Full Text | Free Full Text

24. Bonacchi A, Romagnani P, Romanelli RG: Signal transduction by the chemokine receptor CXCR3: activation of Ras/ERK, Src, and phosphatidylinositol 3-kinase/Akt controls cell migration and proliferation in human vascular pericytes. J Biol Chem. 2001; 276(13): 9945-54. PubMed Abstract | Publisher Full Text

25. Masamune A, Satoh M, Kikuta K, et al.: Activation of JAK-STAT pathway is required for platelet-derived growth factor-induced proliferation of pancreatic stellate cells. World J Gastroenterol. 2005; 11(22): 3385-91. PubMed Abstract | Publisher Full Text | Free Full Text

26. Baumert JT, Sparmann G, Emmrich J, et al.: Inhibitory effects of interferons on pancreatic stellate cell activation. World J Gastroenterol. 2006; 12(6): 896-901.

PubMed Abstract | Free Full Text 
27. Kroeze KL, Boink MA, Sampat-Sardjoepersad SC, et al:: Autocrine regulation of re-epithelialization after wounding by chemokine receptors CCR1, CCR10, CXCR1, CXCR2, and CXCR3. Invest Dermatol. 2012; 132(1): 216-25. PubMed Abstract | Publisher Full Text

28. Yates CC, Whaley D, Hooda S, et al.: Delayed reepithelialization and basement membrane regeneration after wounding in mice lacking CXCR3. Wound Repair Regen. 2009; 17(1): 34-41.

PubMed Abstract | Publisher Full Text | Free Full Text

29. Huen AC, Wells A: The Beginning of the End: CXCR3 Signaling in Late-Stage Wound Healing. Adv Wound Care (New Rochelle). 2012; 1(6): 244-8. PubMed Abstract | Publisher Full Text | Free Full Text

30. Yates CC, Whaley D, Kulasekeran $P$, et al.: Delayed and deficient derma maturation in mice lacking the CXCR3 ELR-negative CXC chemokine receptor. Am J Pathol. 2007; 171(2): 484-95.

PubMed Abstract | Publisher Full Text | Free Full Text

31. Yates CC, Krishna P, Whaley D, et al.: Lack of CXC chemokine receptor 3 signaling leads to hypertrophic and hypercellular scarring. Am J Pathol. 2010; 176(4): 1743-55.

PubMed Abstract | Publisher Full Text | Free Full Text

32. Kouroumalis A, Nibbs RJ, Aptel H, et al:: The chemokines CXCL9, CXCL10, and CXCL11 differentially stimulate $G$ alpha i-independent signaling and actin responses in human intestinal myofibroblasts. J Immunol. 2005 [cited 2019 Feb 15]; 175(8): 5403-11.

PubMed Abstract | Publisher Full Text

33. Campanella GSV, Lee EMJ, Sun J, et al.: CXCR3 and heparin binding sites of the chemokine IP-10 (CXCL10). J Biol Chem. 2003; 278(19): 17066-74. PubMed Abstract | Publisher Full Text

34. Campanella GSV, Grimm J, Manice LA, et al.: Oligomerization of CXCL10 is necessary for endothelial cell presentation and in vivo activity. J Immunol. 2006; 177(10): 6991-8 PubMed Abstract | Publisher Full Text

35. Loos T, Mortier A, Gouwy M, et al.: Citrullination of CXCL10 and CXCL11 by peptidylarginine deiminase: a naturally occurring posttranslational modification of chemokines and new dimension of immunoregulation. Blood. 2008; 112(7): 2648-56.

PubMed Abstract | Publisher Full Text

36. Proost $\mathrm{P}$, Mortier A, Loos T: Proteolytic processing of CXCL11 by CD13 aminopeptidase $\mathrm{N}$ impairs CXCR3 and CXCR7 binding and signaling and reduces lymphocyte and endothelial cell migration. Blood. 2007; 110(1): 37-44.

PubMed Abstract | Publisher Full Text

37. Lambeir AM, Proost $P$, Durinx $C$, et al: Kinetic investigation of chemokine truncation by CD26/dipeptidyl peptidase IV reveals a striking selectivity within the chemokine family. J Biol Chem. 2001; 276(32): 29839-45. PubMed Abstract | Publisher Full Text

38. Proost P, Schutyser E, Menten P, et al.: Amino-terminal truncation of CXCR3 agonists impairs receptor signaling and lymphocyte chemotaxis, while preserving antiangiogenic properties. Blood. 2001; 98(13): 3554-61. PubMed Abstract | Publisher Full Text

39. Vanheule $V$, Janssens $R$, Boff $D$, et al:: The Positively Charged COOH-terminal Glycosaminoglycan-binding CXCL9(74-103) Peptide Inhibits CXCL8-induced Neutrophil Extravasation and Monosodium Urate Crystal-induced Gout in Mice. J Biol Chem. 2015; 290(35): 21292-304.

PubMed Abstract | Publisher Full Text | Free Full Text

40. Vanheule V, Boff D, Mortier A, et al.: CXCL9-Derived Peptides Differentially Inhibit Neutrophil Migration In Vivo through Interference with Glycosaminoglycan Interactions. Front Immunol. 2017; 8: 530. PubMed Abstract | Publisher Full Text | Free Full Text

41. Pasqualini $\mathrm{R}$, Koivunen $\mathrm{E}$, Kain $\mathrm{R}$, et al.: Aminopeptidase $\mathbf{N}$ is a receptor for tumor-homing peptides and a target for inhibiting angiogenesis. Cancer Res. 2000; 60(3): 722-7.

PubMed Abstract | Free Full Text

42. Lasagni L, Francalanci M, Annunziato F: An alternatively spliced variant of CXCR3 mediates the inhibition of endothelial cell growth induced by IP-10, Mig, and I-TAC, and acts as functional receptor for platelet factor 4.J Exp Med. 2003; 197(11): 1537-49.

PubMed Abstract | Publisher Full Text | Free Full Text

43. Ehlert JE, Addison CA, Burdick MD, et al.: Identification and partial characterization of a variant of human CXCR3 generated by posttranscriptional exon skipping. J Immunol. 2004; 173(10): 6234-40. PubMed Abstract | Publisher Full Text

44. Singh AK, Arya RK, Trivedi AK, et al: Chemokine receptor trio: CXCR3, CXCR4 and CXCR7 crosstalk via CXCL11 and CXCL12. Cytokine Growth Factor Rev. 2013: 24(1): 41-9.

PubMed Abstract | Publisher Full Text | Free Full Text

45. Ding BS, Cao Z, Lis R, et al.: Divergent angiocrine signals from vascular niche balance liver regeneration and fibrosis. Nature. 2014; 505(7481): 97-102. PubMed Abstract | Publisher Full Text | Free Full Text

46. Giegold O, Ogrissek N, Richter C, et al.: CXCL9 causes heterologous desensitization of CXCL12-mediated memory T lymphocyte activation. Immunol. 2013; 190(7): 3696-705.

PubMed Abstract | Publisher Full Text

47. Weigold F, Günther J, Pfeiffenberger M, et al.: Antibodies against chemokine receptors CXCR3 and CXCR4 predict progressive deterioration of lung function in patients with systemic sclerosis. Arthritis Res Ther. 2018; 20(1): 52. PubMed Abstract | Publisher Full Text | Free Full Text

48. Recke A, Regensburger AK, Weigold F, et al:: Autoantibodies in Serum of Systemic Scleroderma Patients: Peptide-Based Epitope Mapping Indicates Increased Binding to Cytoplasmic Domains of CXCR3. Front Immunol. 2018; 9. 428 .

PubMed Abstract | Publisher Full Text | Free Full Text

49. Burns JM, Summers BC, Wang Y, et al.: A novel chemokine receptor for SDF-1 and I-TAC involved in cell survival, cell adhesion, and tumor developmen. Exp Med. 2006; 203(9): 2201-13.

PubMed Abstract | Publisher Full Text | Free Full Text

50. Naumann $\mathrm{U}, \mathrm{Cameroni} \mathrm{E}$, Pruenster $\mathrm{M}$, et al:: CXCR7 functions as a scavenger for CXCL12 and CXCL11. PLoS One. 2010; 5(2): e9175.

PubMed Abstract | Publisher Full Text | Free Full Text

51. Guan S, Zhou J: CXCR7 attenuates the TGF- $\beta$-induced endothelial-tomesenchymal transition and pulmonary fibrosis. Mol Biosyst. 2017; 13(10): 2116-24.

PubMed Abstract | Publisher Full Text

52. Cao $Z$, Lis $R$, Ginsberg $M$, et al.: Targeting of the pulmonary capillary vascular niche promotes lung alveolar repair and ameliorates fibrosis. Nat Med. 2016; 22(2): 154-62.

PubMed Abstract | Publisher Full Text | Free Full Text

53. Menke J, Zeller GC, Kikawada E, et al.: CXCL9, but not CXCL10, promotes CXCR3-dependent immune-mediated kidney disease. J Am Soc Nephrol. 2008; 19(6): 1177-89

PubMed Abstract | Publisher Full Text | Free Full Text

54. Koike $\mathrm{K}$, Ueda S, Yamagishi SI, et al.: Protective role of JAK/STAT signaling against renal fibrosis in mice with unilateral ureteral obstruction. Clin Immunol. 2014; 150(1): 78-87.

PubMed Abstract | Publisher Full Text

55. O'Brien JC, Rainwater YB, Malviya N, et al.: Transcriptional and Cytokine Profiles Identify CXCL9 as a Biomarker of Disease Activity in Morphea. Invest Dermatol. 2017; 137(8): 1663-70.

PubMed Abstract | Publisher Full Text | Free Full Text

56. Magee $\mathrm{KE}$, Kelsey $\mathrm{CE}$, Kurzinski $\mathrm{KL}$, et al.: Interferon-gamma inducible protein-10 as a potential biomarker in localized scleroderma. Arthritis Res Ther. 2013; 15(6): R188.

PubMed Abstract | Publisher Full Text | Free Full Text

57. Mertens JS, de Jong A, Pandit A, et al.: Regarding “Transcriptional and Cytokine Profiles Identify CXCL9 as a Biomarker of Disease Activity in Morphea". J Invest Dermatol. 2018; 138(5): 1212-5. PubMed Abstract | Publisher Full Text

58. Rabquer BJ, Tsou PS, Hou Y, et al.: Dysregulated expression of MIG/CXCL9, IP-10/CXCL10 and CXCL16 and their receptors in systemic sclerosis. Arthritis Res Ther. 2011; 13(1): R18. PubMed Abstract | Publisher Full Text | Free Full Text

59. Richmond JM, Patel D, Watanabe T, et al.: An acute bleomycin inflammatory and fibrotic mouse model of morphea is dependent upon CXCL9 and CXCR3. medRxiv. 2019.

Publisher Full Text

60. Hintermann E, Bayer M, Pfeilschifter JM, et al.: CXCL10 promotes liver fibrosis by prevention of NK cell mediated hepatic stellate cell inactivation. $J$ Autoimmun. 2010; 35(4): 424-35.

PubMed Abstract | Publisher Full Text | Free Full Text

61. Shen J, Gao J, Chen C, et al.: Antifibrotic role of chemokine CXCL9 in experimental chronic pancreatitis induced by trinitrobenzene sulfonic acid in rats. Cytokine. 2013; 64(1): 382-94.

PubMed Abstract | Publisher Full Text

62. Zaldivar MM, Berres ML, Sahin H, et al.: The chemokine receptor CXCR3 limits injury after acute toxic liver damage. Lab Invest. 2012; 92(5): 724-34. Publisher Full Text

63. Sahin H, Borkham-Kamphorst E, Kuppe C, et al:: Chemokine Cxcl9 attenuates liver fibrosis-associated angiogenesis in mice. Hepatology. 2012; 55(5): 1610-9. PubMed Abstract | Publisher Full Text

64. Wasmuth HE, Lammert F, Zaldivar MM, et al.: Antifibrotic effects of CXCL9 and its receptor CXCR3 in livers of mice and humans. Gastroenterology. 2009; 137(1): 309-19, 319.e1-3.

PubMed Abstract | Publisher Full Text | Free Full Text

65. Tager AM, Kradin RL, LaCamera $\mathrm{P}$, et al:: Inhibition of pulmonary fibrosis by the chemokine IP-10/CXCL10. Am J Respir Cell Mol Biol. 2004; 31(4): 395-404. PubMed Abstract | Publisher Full Text

66. Jiang D, Liang J, Hodge J, et al.: Regulation of pulmonary fibrosis by chemokine receptor CXCR3. J Clin Invest. 2004; 114(2): 291-9. PubMed Abstract | Publisher Full Text | Free Full Text

67. Jiang D, Liang J, Campanella GS, et al.: Inhibition of pulmonary fibrosis in mice by CXCL10 requires glycosaminoglycan binding and syndecan-4. J Clin Invest. 2010; 120(6): 2049-57.

PubMed Abstract | Publisher Full Text | Free Full Text

68. Tanino $Y$, Wang $X$, Nikaido $T$, et al.: Syndecan-4 Inhibits the Development of Pulmonary Fibrosis by Attenuating TGF- $\beta$ Signaling. Int J Mol Sci. 2019; 20(20): 4989.

PubMed Abstract | Publisher Full Text | Free Full Text 
69. Saxena A, Bujak M, Frunza O, et al.: CXCR3-independent actions of the CXC chemokine CXCL10 in the infarcted myocardium and in isolated cardiac fibroblasts are mediated through proteoglycans. Cardiovasc Res. 2014; 103(2): 217-27.

PubMed Abstract | Publisher Full Text | Free Full Text

70. Xie H, Feng C, Fu Q, et al.: Crosstalk between TGF- $\beta 1$ and CXCR3 signaling during urethral fibrosis. Mol Cell Biochem. 2014; 394(1-2): 283-90. PubMed Abstract | Publisher Full Text

71. Burdick MD, Murray LA, Keane MP, et al.: CXCL11 attenuates bleomycininduced pulmonary fibrosis via inhibition of vascular remodeling. $\mathrm{Am}$ Respir Crit Care Med. 2005; 171(3): 261-8.

PubMed Abstract | Publisher Full Text

72. Strieter RM, Starko KM, Enelow RI, et al:: Effects of interferon-gamma 1b on biomarker expression in patients with idiopathic pulmonary fibrosis. $\mathrm{Am}$ Respir Crit Care Med. 2004; 170(2): 133-40.

PubMed Abstract | Publisher Full Text

73. Damsky W, Patel D, Garelli CJ, et al.: Jak Inhibition Prevents Bleomycin Induced Fibrosis in Mice and Is Effective in Patients with Morphea. J Invest Dermatol. 2020; 140(7): 1446-1449.e4.

PubMed Abstract | Publisher Full Text

74. Dees C, Tomcik M, Palumbo-Zerr K, et al.: JAK-2 as a novel mediator of the profibrotic effects of transforming growth factor $\beta$ in systemic sclerosis. Arthritis Rheum. 2012; 64(9): 3006-15.

PubMed Abstract | Publisher Full Text

75. Wang W, Bhattacharyya S, Marangoni RG, et al.: The JAK/STAT pathway is activated in systemic sclerosis and is effectively targeted by tofacitinib. J Scleroderma Relat Disord. 2020; 5(1): 40-50. Publisher Full Text

76. Kim SR, Charos A, Damsky W, et al: Treatment of generalized deep morphea and eosinophilic fasciitis with the Janus kinase inhibitor tofacitinib. JAAD Case Rep. 2018; 4(5): 443-5.

PubMed Abstract | Publisher Full Text | Free Full Text

77. Zhang $Y$, Liang $R$, Chen CW, et al: JAK1-dependent transphosphorylation of JAK2 limits the antifibrotic effects of selective JAK2 inhibitors on long-term treatment. Ann Rheum Dis. 2017; 76(8): 1467-75.

PubMed Abstract | Publisher Full Text

78. Deisseroth A, Kaminskas E, Grillo J, et al.: U.S. Food and Drug Administration approval: ruxolitinib for the treatment of patients with intermediate and high-risk myelofibrosis. Clin Cancer Res. 2012; 18(12): 3212-7. PubMed Abstract | Publisher Full Text

79. Molica M, Serrao A, Saracino R, et al.: Disappearance of fibrosis in secondary myelofibrosis after ruxolitinib treatment: new endpoint to achieve? Ann Hematol. 2014; 93(11): 1951-2.

PubMed Abstract | Publisher Full Text

80. Tefferi A, Pardanani A: Serious adverse events during ruxolitinib treatment discontinuation in patients with myelofibrosis. Mayo Clin Proc. 2011; 86(12): 1188-91.

PubMed Abstract | Publisher Full Text | Free Full Text

81. Coltro G, Mannelli $F$, Guglielmelli $P$, et al.: A life-threatening ruxolitinib discontinuation syndrome. Am J Hematol. 2017; 92(8): 833-8. PubMed Abstract | Publisher Full Text

82. Tvorogov D, Thomas D, Liau NPD, et al.: Accumulation of JAK activation loop phosphorylation is linked to type I JAK inhibitor withdrawal syndrome in myelofibrosis. Sci Adv. 2018; 4(11): eaat3834.

PubMed Abstract | Publisher Full Text | Free Full Text

83. Markham A: Baricitinib: First Global Approval. Drugs. 2017; 77(6): 697-704. PubMed Abstract | Publisher Full Text

84. Ackermann $\mathrm{M}$, Verleden $\mathrm{SE}$, Kuehnel $\mathrm{M}$, et al:: Pulmonary Vascular Endothelialitis, Thrombosis, and Angiogenesis in Covid-19. N Engl] Med. 2020; 383(2): 120-8.

PubMed Abstract | Publisher Full Text | Free Full Text

85. Bonvin P, Gueneau F, Buatois V, et al.: Antibody Neutralization of CXCL10 in Vivo Is Dependent on Binding to Free and Not Endothelial-bound Chemokine: IMPLICATIONS FOR THE DESIGN OF A NEW GENERATION OF ANTI-CHEMOKINE THERAPEUTIC ANTIBODIES. J Biol Chem. 2017; 292(10): 4185-97.

PubMed Abstract | Publisher Full Text | Free Full Text

86. Zolot RS, Basu S, Million RP: Antibody-drug conjugates. Nat Rev Drug Discov. 2013; 12(4): 259-60.

PubMed Abstract | Publisher Full Text

87. Bargh JD, Isidro-Llobet A, Parker JS, et al.: Cleavable linkers in antibody-drug conjugates. Chem Soc Rev. 2019; 48(16): 4361-74. PubMed Abstract | Publisher Full Text

88. Wilhelm S, Tavares AJ, Dai Q, et al.: Analysis of nanoparticle delivery to tumours. Nat Rev Mater. 2016; 1(5): 16014.

Publisher Full Text

89. Labrijn AF, Janmaat ML, Reichert JM, et al.: Bispecific antibodies: a mechanistic review of the pipeline. Nat Rev Drug Discov. 2019; 18(8): 585-608. PubMed Abstract | Publisher Full Text

90. Prow TW, Grice JE, Lin LL, et al.: Nanoparticles and microparticles for skin drug delivery. Adv Drug Deliv Rev. 2011; 63(6): 470-91. PubMed Abstract | Publisher Full Text

91. Prausnitz MR: Microneedles for transdermal drug delivery. Adv Drug Deliv Rev. 2004; 56(5): 581-7.

PubMed Abstract | Publisher Full Text

92. Hirakawa $\mathrm{H}$, Zempo $\mathrm{H}$, Ogawa $\mathrm{M}$, et al.: A DPP-4 inhibitor suppresses fibrosis and inflammation on experimental autoimmune myocarditis in mice. PLOS One. 2015; 10(3): e0119360.

PubMed Abstract | Publisher Full Text | Free Full Text

93. Kanasaki K, Shi S, Kanasaki M, et al.: Linagliptin-mediated DPP-4 inhibition ameliorates kidney fibrosis in streptozotocin-induced diabetic mice by inhibiting endothelial-to-mesenchymal transition in a therapeutic regimen. Diabetes. 2014; 63(6): 2120-31. PubMed Abstract | Publisher Full Text

94. Liu Y, Qi Y: Vildagliptin, a CD26/DPP4 inhibitor, ameliorates bleomycininduced pulmonary fibrosis via regulating the extracellular matrix. Int Immunopharmacol. 2020; 87: 106774. Immunopharmacol. 2020; 87: 106774.

95. Kühlmann UC, Chwieralski CE, van den Brule S, et al.: Modulation of cytokine production and silica-induced lung fibrosis by inhibitors of aminopeptidase $\mathbf{N}$ and of dipeptidyl peptidase-IV-related proteases. Life SCi. 2009; 84(1-2): 1-11.

PubMed Abstract | Publisher Full Text

96. Wynn TA, Ramalingam TR: Mechanisms of fibrosis: therapeutic translation for fibrotic disease. Nat Med. 2012; 18(7): 1028-40. PubMed Abstract | Publisher Full Text | Free Full Text 


\section{Open Peer Review}

\section{Current Peer Review Status:}

\section{Version 1}

Reviewer Report 22 October 2020

https://doi.org/10.5256/f1000research.29512.r72472

(C) 2020 Pioli P. This is an open access peer review report distributed under the terms of the Creative Commons Attribution License, which permits unrestricted use, distribution, and reproduction in any medium, provided the original work is properly cited.

\section{Patricia A. Pioli}

Department of Microbiology and Immunology, Geisel School of Medicine, Lebanon, NH, USA

This report provides an excellent summary of the role of CXCR3 and associated ligands (CXCL9, 10 and 11) in fibrosis. Significantly, these mediators have been reported to have both pro- and antifibrotic effects, which potentially confounds their importance in the regulation of fibrotic activation. One of the strengths of this report is that it provides an explanation for these ostensibly opposing effects by emphasizing the importance of cell and tissue context and the role of angiogenesis. Indeed, rather than serving redundant functions, it is likely that the relative contribution of these chemokines is dictated by the extent of vascularization and the cell type responsible for mediating tissue damage. As suggested by the authors, the use of combination therapies is likely to generate the most therapeutic benefit to patients, and the last section of this review does an excellent job of summarizing treatment targets. Although beyond the scope of this current article, future reviews may investigate the utility of specifically targeting immune subpopulations as sources of these chemokines.

Is the topic of the opinion article discussed accurately in the context of the current literature?

Yes

\section{Are all factual statements correct and adequately supported by citations?} Yes

\section{Are arguments sufficiently supported by evidence from the published literature?} Yes

Are the conclusions drawn balanced and justified on the basis of the presented arguments? Yes

Competing Interests: No competing interests were disclosed. 
Reviewer Expertise: macrophage activation in fibrotic disease, including systemic sclerosis

I confirm that I have read this submission and believe that I have an appropriate level of expertise to confirm that it is of an acceptable scientific standard.

Author Response 22 Oct 2020

Jillian Richmond, University of Massachussetts Medical School, Worcester, USA

We thank Dr. Pioli for taking the time to review our opinion article. We agree that future studies/reviews could focus on targeting specific immune cell populations in the context of different fibrosing disorders.

Competing Interests: No competing interests were disclosed.

Reviewer Report 16 October 2020

https://doi.org/10.5256/f1000research.29512.r72473

(C) $\mathbf{2 0 2 0}$ Sadik C. This is an open access peer review report distributed under the terms of the Creative Commons Attribution License, which permits unrestricted use, distribution, and reproduction in any medium, provided the original work is properly cited.

\section{Christian D. Sadik}

${ }^{1}$ Department of Dermatology, Allergy, and Venereology, University of Lübeck, Lübeck, Germany

2 Center for Research on Inflammation of the Skin (CRIS), Lübeck, Germany

The review focuses on the role of CXCR3 and its ligands in fibrotic processes. It starts with an excellent overview on the complex receptor pharmacology of CXCR3 and continues to exhaustively summarize and discuss the role of CXCR3 in the fibrotic processes in different organs.

The review is very illustrative including excellent figures. The current state of knowledge on CXCR3 and its role in fibrotic processes is comprehensively summarized and discussed in a balanced manner. All in the article are supported by the literature, which is adequately cited.

Is the topic of the opinion article discussed accurately in the context of the current literature?

Yes

Are all factual statements correct and adequately supported by citations? Yes

Are arguments sufficiently supported by evidence from the published literature? Yes

Are the conclusions drawn balanced and justified on the basis of the presented arguments? 
Yes

Competing Interests: No competing interests were disclosed.

Reviewer Expertise: My areas of research are innate immunity, immomediators, immunopharmacology, and autoimmune and autoinflammatory diseases

I confirm that I have read this submission and believe that I have an appropriate level of expertise to confirm that it is of an acceptable scientific standard.

Author Response 19 Oct 2020

Jillian Richmond, University of Massachussetts Medical School, Worcester, USA

We thank Dr. Sadik for taking the time to review our opinion article.

Competing Interests: No competing interests were disclosed.

The benefits of publishing with F1000Research:

- Your article is published within days, with no editorial bias

- You can publish traditional articles, null/negative results, case reports, data notes and more

- The peer review process is transparent and collaborative

- Your article is indexed in PubMed after passing peer review

- Dedicated customer support at every stage

For pre-submission enquiries, contact research@f1000.com

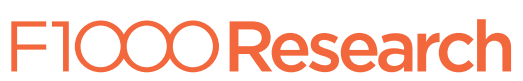

